TECHNICAL NOTES AND MANUALS

\title{
Expenditure Assessment Tool (EAT)
}

Prepared by Mercedes Garcia-Escribano and Candice Yue Liu

Fiscal Affairs Department

I NTERNATIONAL MONETARY FUND 
TECHNICAL NOTES AND MANUALS

Rights Link

Expenditure Assessment Tool (EAT)

Prepared by Mercedes Garcia-Escribano and Candice Ye Liu Fiscal Affairs Department

I NT ER NA TI ON A L M ONETARYA F D

CInternational Monetary Fund. Not for Redistribution 


\section{INTERNATIONAL MONETARY FUND}

Fiscal Affairs Department

\section{Expenditure Assessment Tool (EAT)}

Prepared by Mercedes Garcia-Escribano and Candice Yue Liu

April 2017

DISCLAIMER: This Technical Guidance Note should not be reported as representing the views of the IMF. The views expressed in this Note are those of the Authors and do not necessarily represent those of the IMF or IMF policy.

\begin{tabular}{|l|l|}
\hline JEL Classification Numbers: & E62, H5, H11, I18, I28 \\
\hline Keywords: & Public expenditure review, spending efficiency, benchmarking \\
\hline Authors' E-Mail Addresses: & $\begin{array}{l}\text { mgarciaescribano@imf.org } \\
\text { yliu2@imf.org }\end{array}$ \\
\hline
\end{tabular}




\section{TECHNICAL NOTES AND MANUALS}

\section{Expenditure Assessment Tool (EAT)1}

\section{ABSTRACT}

This manual presents the Expenditure Assessment Tool (EAT), which helps assess expenditures for any specific country. EAT uses the commonly available software program Excel and has been designed by Expenditure Policy Division at Fiscal Affairs Department at IMF. The information EAT provides can be very useful in the evaluation of government spending and in the identification of areas where there may be room to increase spending efficiency or rationalize spending. The evaluation is done through benchmarking of spending - levels, composition and outcomes-against regional and income comparators. The focus is on both the economic and functional classification of expenditures. The application of the tool to spending in Argentina is presented as an illustration.

\footnotetext{
${ }^{1}$ The authors are grateful to David Coady, Angana Banerji, Dora Benedek, Ben Clements, Paolo Dudine, Christoph Duenwald, Yehenew Endegnanew, Judith Gold, Jean-Jacques Hallaert, Yuko Hashimoto, Christopher Iles, Elena Loukoianova, Lusine Lusinyan, Jean Pierre Nguenang, Joana Pereira, Jacqueline Rothfels, Isabel Rial, Diva Singh, Patrizia Tumbarello, and Edda Zoli, for insightful feedback, and participants of the IMF FAD seminar held on June 29, 2016 and IMF AFR Fiscal Network seminar held December 14, 2016 for their helpful comments and suggestions. We also thank Ana Popovich and Liza Prado for their assistance.
} 


\section{CONTENTS}

I. Introduction $\ldots \ldots \ldots \ldots \ldots \ldots \ldots \ldots \ldots \ldots \ldots \ldots \ldots \ldots \ldots \ldots, \ldots, 4$

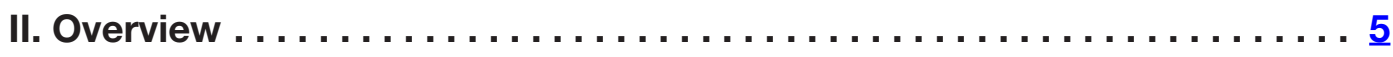

A. Country of Choice and Comparators $\ldots \ldots \ldots \ldots \ldots \ldots \ldots \ldots \ldots \ldots \ldots \ldots \ldots \ldots \ldots \ldots \ldots$

III. Government Spending by Economic Classification. . . . . . . . . $\underline{8}$

A. Total Government Spending. . . . . . . . . . . . . . . . . . . . . . . $\underline{8}$

B. Compensation and Employment $\ldots \ldots \ldots \ldots \ldots \ldots \ldots \ldots \ldots \ldots \ldots \ldots \ldots \ldots \ldots \ldots \ldots \ldots \ldots$

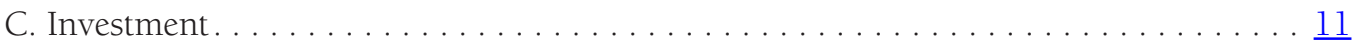

D. Energy Subsidies . . . . . . . . . . . . . . . . . . . .

IV. Government Spending by Functional Classification . . . . . . . . . 13

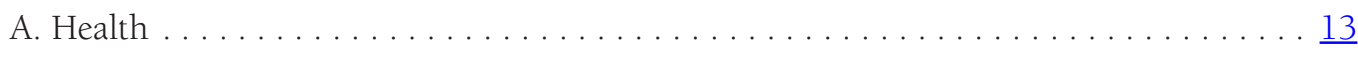

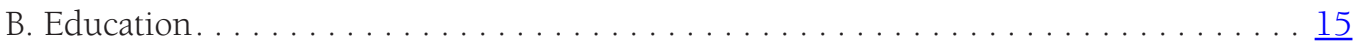

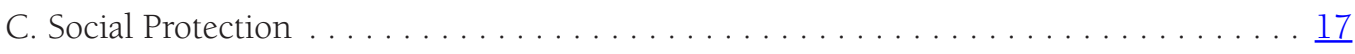

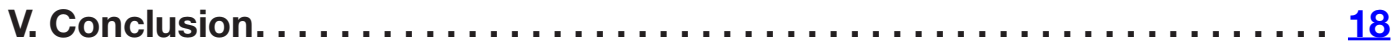

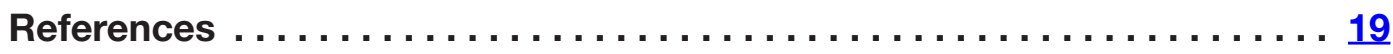

\section{Tables}

1. Options for Regional Breakdown $\ldots \ldots \ldots \ldots \ldots \ldots \ldots \ldots \ldots \ldots \ldots \ldots \ldots \ldots \ldots \ldots \ldots \ldots \ldots$

\section{Figures}

1. Expenditure Assessment Tool: "Index" Tab . . . . . . . . . . . . . . . . $\underline{6}$

2. Choice of Country and Comparators: "Select Country \& Comparators" Tab. . . . . . . . $\underline{8}$

3. Government Spending and Economic Classification................ 21

4. Government Wage Bill . . . . . . . . . . . . . . . . . . . . . 22

5. Investment Infrastructure . . . . . . . . . . . . . . . . . . 23

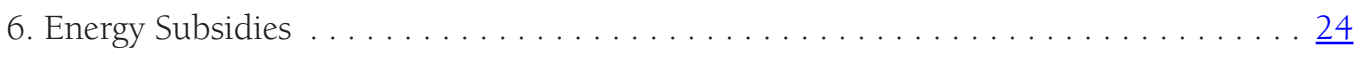

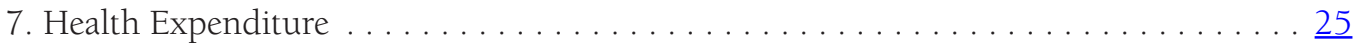

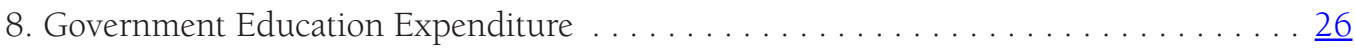

9. Social Protection. .......................... 27 


\section{ACRONYMS}

\begin{tabular}{|c|c|}
\hline AEs & Advanced Economies \\
\hline ASPIRE & The Atlas of Social Protection - Indicators of Resilience and Equity \\
\hline DEA & Data Envelopment Analysis \\
\hline EAT & Expenditure Assessment Tool \\
\hline EMs & Emerging Markets \\
\hline EPD & Expenditure Policy Division \\
\hline FAD & Fiscal Affairs Department \\
\hline FM & Fiscal Monitor \\
\hline GFS & Government Finance Statistics \\
\hline HALE & Healthy Life Expectancy \\
\hline IMF & International Monetary Fund \\
\hline LAC & Latin America and Caribbean \\
\hline LIDCs & Low-Income Developing Countries \\
\hline OECD & Organization for Economic Co-operation and Development \\
\hline PISA & Program for International Student Assessment \\
\hline WB & World Bank \\
\hline WDI & World Development Indicators \\
\hline WEF & World Economic Forum \\
\hline WEO & World Economic Outlook \\
\hline WHO & World Health Organization \\
\hline
\end{tabular}




\section{INTRODUCTION}

Reforming public expenditures has come to the forefront of the policy agenda in many countries. Advanced economies (AEs) face the challenge of containing or consolidating overall spending to meet fiscal targets while responding to pressures that raise expenditures related to aging (Clements et al., 2015a; and IMF, 2014a). ${ }^{2}$ Emerging markets (EMs) and low-income and developing countries (LIDCs) with limited resource mobilization capacity in the short term strive to improve spending efficiency to create the needed fiscal space to finance the expansion of priority spending on education, health and infrastructure (IMF, 2014a).

The evaluation of government spending can help identify areas where there may be room to increase spending efficiency or rationalize spending. Country experience shows that streamlining expenditures is politically difficult to implement. This is in part because of concerns about the social impact of spending cuts. As a result, many countries have adopted across-the-board containment measures rather than pursuing deeper efficiency-oriented reforms. But across-theboard measures offer only short-term relief and risk undermining the desired social objectives. For this reason, providing information that helps identify areas where there may be room to improve spending efficiency or reduce or contain spending, without affecting the quality of the services delivered, is a key component of a well-designed spending reform.

This paper presents the Expenditure Assessment Tool (EAT), which is a tool that provides information to help assess public expenditures. Using data on economic and functional classification of expenditures, the tool provides benchmarks of spending-levels and composition-against comparators. ${ }^{3,4}$ EAT offers three comparator groups for benchmarking. In particular, it allows choosing comparators according to the region and income group, as well as adding the Organization for Economic Co-operation and Development (OECD) as a comparator. Spending is also assessed relative to outcomes. ${ }^{5}$ This assessment helps to get a sense of spending efficiency and supplements the insights on efficiency gleaned from the analysis of the size and composition of economic and functional expenditures.

EAT is a user-friendly Excel-based tool. The tool is relatively straightforward to use as it relies on an Excel-based template populated with data on expenditures drawn from different sources (see Section II). The tool requires that the user specifies the country of choice and its comparator groups.

\footnotetext{
${ }^{2}$ Recently the Eurogroup has explicitly recognized the importance of public expenditure reviews in improving the quality of public spending in support of enhancing fiscal responsibility (Eurogroup, 2016).

${ }^{3}$ Examples of analytical work on prioritizing expenditures and enhancing spending efficiency based on a benchmarking approach include Chailloux et al. (2016), Coady and Geng (2015), Gaertner and Queyranne (2015), Hallaert (2016), Hallaert and Queyranne (2016), and IMF (2013c).

${ }^{4}$ The reader may wish to refer to the IMF Government Finance Statistical Manual 2014 for the concept of expense and detailed description on the manner in which expense is classified (IMF, 2014b).

${ }^{5}$ In this manual, the words outcomes and outputs are used indistinctively.
} 
The tool is not a substitute for an in-depth spending review. EAT relies on cross-country benchmarking of a narrow set of inputs and outputs that are available. Therefore, it provides a starting point to guide a more detailed and refined sectoral analysis focused on a broader set of inputs and outputs. In addition, elements, such as a detailed analysis of the distributional impact of expenditure cuts, that are crucial inputs into policy decisions, escape this tool. The assessment of efficiency gains need to be supplemented by econometric approaches that allow to control for country-specific factors, such as the country income level. Also, variations in input-outcome relationships within a country can offer important insights for improving spending efficiency. Addressing legal restrictions, which are essential when designing a spending reform, also escape the tool. Last, cross-country variation in spending may reflect national choices. The role of the public sector-for example, for education, pensions, and health-reflects country's preferences.

The rest of the manual is structured as follows. Section II provides an overview of the tool. Section III presents and discusses the outputs produced by the tool when benchmarking spending according to the economic classification. Sections IV presents the outputs from the benchmarking of spending by functional classification. Section V concludes. An application of the tool to Argentina is presented as an illustration.

\section{OVERVIEW}

EAT comprises information for all IMF member countries. All fiscal data refer to the general government (i.e., central plus subnational governments), unless indicated otherwise. This coverage ensures, as much as possible, the use of comparable data available for a large number of countries and coincides with the fiscal coverage and general government definition used in the IMF World Economic Outlook (WEO) and Fiscal Monitor (FM) publications.

Sources for the data, as shown in the "Index" tab displayed in Figure 1, include the WEO, ASPIRE6 by World Bank (WB), World Development Indicators (WDI) by WB, World Economic Forum (WEF), and World Health Organization (WHO). Some of the indicators-in particular, public capital stock, government wage bill and employment, public sector wage premium, energy subsidies, and pensions_-are compiled and maintained by Expenditure Policy Division (EPD) of Fiscal Affairs Department (FAD) at the IMF. Sources for the data are listed in the respective figures. Data can be accessed by using the link provided under each chart.

The data used in this illustration are based on the October 2016 WEO and the values drawn from the rest of the sources in October 2016. The database presented in the tool will be updated twice a year in order to reflect the latest available information and ensure consistency with the publicly released WEO database. As some users may wish to assess expenditures in a

\footnotetext{
${ }^{6}$ ASPIRE stands for "The Atlas of Social Protection - Indicators of Resilience and Equity".
} 
particular country against comparators overtime, the tool includes in each of its spending tabs a lookup field that displays the list of years (ranging from 2000 to 2015) from which the user can make a choice.

Figure 1. Expenditure Assessment Tool: "Index" Tab

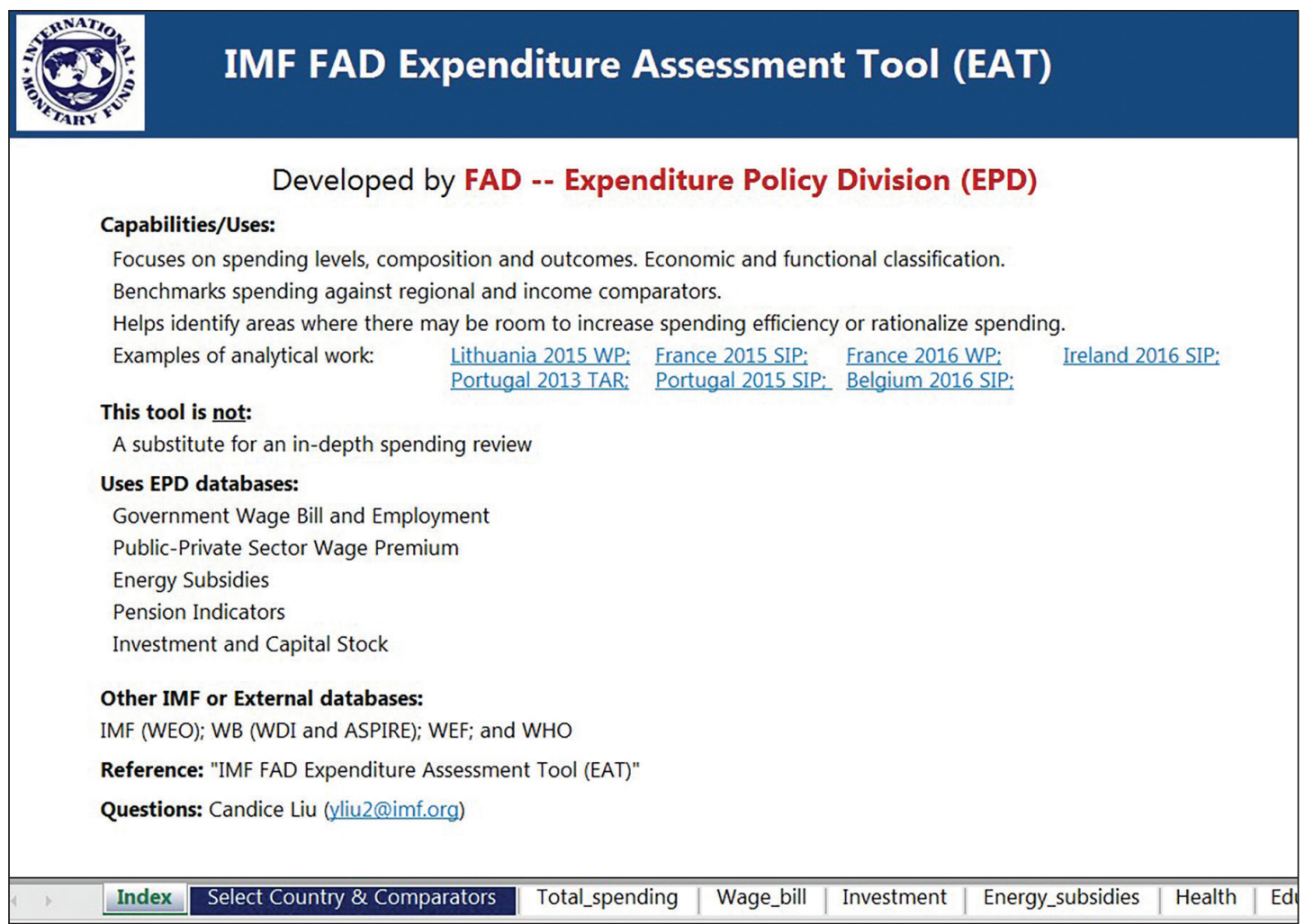

Source: IMF FAD Expenditure Assessment Tool (EAT).

\section{A. Country of Choice and Comparators}

Running EAT for a country requires specifying the country of interest and corresponding benchmarks in the "selection" tab (Figure 2). The tool offers benchmark options by income group (AEs, EMs, LIDCs) and region. The range of options for the regional breakdown is shown in Table 1. EAT also allows the possibility of adding OECD as a third benchmark. Once the user specifies these choices, the charts automatically display data for the chosen country and the simple averages for the comparator groups. Some charts also show individual-country data for the regional comparators. 


\begin{tabular}{|c|c|}
\hline AEs & Advanced Economies \\
\hline EU & European Union (28 countries included) \\
\hline Eurozone & Euro Area (19 countries) \\
\hline SSA & Sub-Saharan Africa \\
\hline CEMAC & $\begin{array}{l}\text { Economic and Monetary Community of Central African States: Cameroon, Central African Republic, Chad, Equatorial } \\
\text { Guinea, Gabon, and Republic of Congo }\end{array}$ \\
\hline COMESA & $\begin{array}{l}\text { Common Market of Eastern and Southern Africa: Burundi, Comoros, Democratic Republic of Congo, Eritrea, Ethiopia, Kenya, } \\
\text { Madagascar, Malawi, Mauritius, Rwanda, Seychelles, Swaziland, Uganda, Zambia, and Zimbabwe }\end{array}$ \\
\hline SADC & $\begin{array}{l}\text { Southern African Development Community: Angola, Botswana, Democratic Republic of Congo, Lesotho, Madagascar, } \\
\text { Malawi, Mauritius, Mozambique, Namibia, Seychelles, South Africa, Swaziland, Tanzania, Zambia, and Zimbabwe }\end{array}$ \\
\hline EAC & East Africa Community: Burundi, Kenya, Tanzania, Uganda, and Rwanda \\
\hline ECOWAS & $\begin{array}{l}\text { Economic Community of West African States: Benin, Burkina Faso, Cabo Verde, Cote d'Ivoire, The Gambia, Ghana, Guinea, } \\
\text { Guinea-Bissau, Liberia, Mali, Niger, Nigeria, Senegal, Sierra Leone, and Togo }\end{array}$ \\
\hline WAEMU & $\begin{array}{l}\text { West African Economic and Monetary Union: Benin, Burkina Faso, Code d'Ivoire, Guinea-Bissau, Mali, Niger, } \\
\text { Senegal, and Togo }\end{array}$ \\
\hline GCC & Gulf Cooperation Council countries: Bahrain, Kuwait, Oman, Qatar, Saudi Arabia, and the United Arab Emirates \\
\hline MENAP & Middle East, North Africa, Afghanistan, and Pakistan \\
\hline MENAP Oil Importers & Afghanistan, Djibouti, Egypt, Jordan, Lebanon, Mauritania, Morocco, Pakistan, Sudan, Syria, and Tunisia \\
\hline MENAP Oil Exporters & Algeria, Bahrain, Iran, Iraq, Kuwait, Libya, Oman, Qatar, Saudi Arabia, United Arab Emirates, and Yemen \\
\hline CCA & $\begin{array}{l}\text { Caucasus and Central Asia: Armenia, Azerbaijan, Georgia, Kazakhstan, Kyrgyz Republic, Tajikistan, Turkmenistan, } \\
\text { and Uzbekistan }\end{array}$ \\
\hline CIS & $\begin{array}{l}\text { Commonwealth of Independent States: Armenia, Azerbaijan, Belarus, Georgia, Kazakhstan, Kyrgyz Republic, Moldova, } \\
\text { Russia, Tajikistan, Turkmenistan, Ukraine, and Uzbekistan }\end{array}$ \\
\hline EM Asia & $\begin{array}{l}\text { Emerging and Developing Asia: Bangladesh, Bhutan, Brunei Darussalam, Cambodia, China, Fiji, India, Indonesia, Kiribati, } \\
\text { Lao P.D.R., Malaysia, Maldives, Marshall Islands, Micronesia, Mongolia, Myanmar, Nepal, Palau, Papua New Guinea, } \\
\text { Philippines, Samoa, Solomon Islands, Sri Lanka, Thailand, Democratic Republic of Timor-Leste, Tonga, Tuvalu, and Vanuatu }\end{array}$ \\
\hline $\begin{array}{l}\text { Pacific Islands } \\
\text { and Small States }\end{array}$ & $\begin{array}{l}\text { Pacific island countries and other small states: Bhutan, Fiji, Kiribati, Maldives, Marshall Islands, Micronesia, Mongolia, } \\
\text { Palau, Papua New Guinea, Samoa, Solomon Islands, Democratic Republic of Timor-Leste, Tonga, Tuvalu, and Vanuatu }\end{array}$ \\
\hline ASEAN & Singapore, Brunei Darussalam, Cambodia, Indonesia, Lao P.D.R., Malaysia, Myanmar, Philippines, Thailand, and Vietnam \\
\hline ASEAN5 & Indonesia, Malaysia, Philippines, Singapore, and Thailand \\
\hline EM Europe & $\begin{array}{l}\text { Emerging and Developing Europe: Albania, Bosnia and Herzegovina, Bulgaria, Croatia, FYR Macedonia, Hungary, Kosovo, } \\
\text { Republic of Montenegro, Poland, Romania, Serbia, and Turkey }\end{array}$ \\
\hline CESEE & $\begin{array}{l}\text { Central, Eastern and Southeastern Europe: Czech Republic, Estonia, Latvia, Lithuania, Slovak Republic, Bulgaria, } \\
\text { Croatia, Hungary, Poland, and Romania }\end{array}$ \\
\hline Latin America & Central America and South America \\
\hline South America & Argentina, Bolivia, Brazil, Chile, Colombia, Ecuador, Guyana, Mexico, Paraguay, Peru, Suriname, Uruguay, and Venezuela \\
\hline Central America & Belize, Costa Rica, El Salvador, Guatemala, Honduras, Nicaragua, and Panama \\
\hline Caribbean & $\begin{array}{l}\text { Antigua and Barbuda, The Bahamas, Barbados, Dominica, Dominican Republic, Grenada, Haiti, Jamaica, } \\
\text { St. Kitts and Nevis, St. Lucia, St. Vincent and the Grenadines, Trinidad and Tobago }\end{array}$ \\
\hline LAC & Latin America and Caribbean \\
\hline LA6 & Brazil, Chile, Colombia, Mexico, Peru, and Uruguay \\
\hline Fragile States & 37 Fragile States (IMF, 2015b) \\
\hline
\end{tabular}

Source: IMF FAD Expenditure Assessment Tool (EAT).

\section{CInternational Monetary Fund. Not for Redistribution}


Figure 2. Choice of Country and Comparators: "Select Country \& Comparators" Tab

\begin{tabular}{l} 
Select Country and Comparators from Drop-Down Menu \\
Step 1. Select country of interest \\
Step 2. Select benchmark by region group \\
Step 3. Select benchmark by income group \\
Step 4. Include oECD as benchmark \\
LAC \\
Notes: \\
1/ Benchmarks are the averages of the countries included in the region/income/OECD group. \\
2/ There are hyperlinks ("Data ->") under each chart which will direct you to the underlying data table. In the data table, there are \\
hyperlinks ("Charts") under each indicator that will link back to the corresponding charts. \\
\hline Index Select Country \& Comparators Total_spending | Wage_bill | Investment | Energy_subsidies | Health | Education | Social | Cross | Tres
\end{tabular}

Source: IMF FAD Expenditure Assessment Tool (EAT).

\section{GOVERNMENT SPENDING BY ECONOMIC CLASSIFICATION}

The tabs "Total_spending", "Wage_bill", "Investment", and "Energy Subsidies" display the panels for the benchmarking of spending by economic classification.

\section{A. Total Government Spending}

Figure 3 displays the trends for revenues and expenditures, in percent of GDP, for the country of choice. Recent dynamics could reveal the source of recent spending pressures or areas where future spending pressures may emerge-for example, after a steep decline in expenditures amidst a fiscal consolidation period. A steady and prolonged increase in expenditures may also indicate sources of difficulties in containing expenditures. Changes in total spending could be less of a concern if these are similar to those experienced by comparator countries, and especially, if the level of expenditure for the country of choice stands around the average of the comparator group.

Information on the composition of the change in total spending is also provided as well as information on the current structure of the budget. ${ }^{7}$ The charts display the composition of the change or adjustment in terms of the contribution of current and capital spending. Such information can inform an assessment of the quality of a recently implemented adjustment or budgetary expansion. For example, it could be the case that capital spending declined while

\footnotetext{
${ }^{7}$ Budget refers to total expenditures for the general government, as defined in the WEO, rather than to the narrower definition of central government budget.
} 
current spending increased. An assessment of the current structure of the budget in terms of its composition by economic classification-in particular, use of goods and services, compensation of employees, interests, other current spending (which includes social benefits, subsidies to public corporations and private enterprises, and grants), and consumption of fixed capitalwill allow identification of items that are sizable when compared to the average structure of the budget of comparator countries.

\section{Data}

Data on revenues, expenditures, and the break-down of expenditures by economic classification are drawn from the World Economic Outlook. ${ }^{8}$

\section{Case study}

Over the past decade, spending in Argentina has outpaced GDP growth as well as the spending increase exhibited by most comparators. During 2004-15, expenditures grew by 17.6 percentage points of GDP while revenues grew more slowly, resulting in a gradual decline in the fiscal overall balance. Reflecting these dynamics, the fiscal balance registered a deficit estimated at 6.6 percent of GDP in 2015. Spending in most comparators also grew during this period, but the increase was lower and averaged 4.9 percentage points of GDP in Latin American and Caribbean (LAC) and about 5.3 percentage points of GDP in EMs.

Government expenditure in Argentina is significantly above the LAC and EM averages, and it is heavily tilted towards current expenditures. Argentina's government spends 40.6 percent of GDP, 10.5 percentage points of GDP more than the LAC average. When assessing the composition, current spending represents 37 percent of GDP (90 percent of total expenditures) compared to 83 percent of total expenditures for the LAC average. The budget structure is heavily tilted towards current spending reflecting spending growth having been primarily driven by current spending.

High current spending is reflected across most economic categories, but especially for the wage bill and other current spending. Other current spending includes spending on social benefits, which in the case of Argentina is substantially above the LAC average. ${ }^{9}$ Spending on social benefits represents about 261/2 percent of total expenditures, in contrast to about 18 percent in the average LAC country. Spending on compensation of employees is also slightly above the LAC average. In the sections that follow, we take a deeper look into individual economic and functional spending categories.

\footnotetext{
${ }^{8}$ Detailed data on government expenses is also available for Government Finance Statistics (GFS) reporting countries from the IMF Government Finance Statistics.

${ }^{9}$ Social benefits are transfers in cash or in kind to protect the entire population or specific segments of it against certain social risks. Examples of social benefits are the provision of medical services, unemployment compensation, and social security pensions (IMF, 2014b).
}

Technical Notes and Manuals 17/06 | 2017

\section{CInternational Monetary Fund. Not for Redistribution}




\section{B. Compensation and Employment}

Figure 4 focuses on the wage bill, which is usually a major item in government spending (on average it represents about a quarter of the budget). The trends of the general government wage bill in relation to GDP and of public employment as a share of working age population are displayed. Recent dynamics could reveal if the country of choice faces difficulties in reigning in wage bill spending. For example, countries usually find it difficult to contain wage bill spending before elections and during times of economic upswings (IMF, 2016f). Recent dynamics could also tell if a country has pursued a reform strategy and if the results of such reform were short or long lived.

Several charts are presented to allow a more detailed diagnostic of the wage bill. Comparing the size of the wage bill (in terms of GDP or of total spending) to the regional and income group averages informs if the wage bill is excessive. The charts also reveal if the underlying reason for an elevated wage bill — which is the product of employment and compensation levels—is a generous employment or compensation policy. Such distinction is important for streamlining or containing the wage bill. For example, if the wage bill is high because of a large share of public employees, measures on employment—such as attrition—can be effective in providing short-term relief. ${ }^{10}$ Alternatively, if the wage bill is high because government wages are high relative to the private sector, containing compensation can be a strategy to enhance the efficiency of spending (IMF, 2016f). Indeed, compensation measures are usually part of any wage bill reform as, on average, public sector wages are often higher than private wages for comparably skilled workers-with the wage premium being lower for AEs (at around 51/2 percent) compared to EMs and LIDCs (at around 121/4 percent) (IMF, 2016a; and IMF, 2016f).

The assessment of the government wage bill and specific proposals for its reform need to be supplemented with a deeper analysis. Further information on wage differentials within the public sector to ensure horizontal equity would shed further light to better guide a public sector reform. Similarly, information on wage compression-defined as the gap between the premium for highskilled compared to low-skilled-relative to the private sector will inform if the wage structure is adequate to attract and retain qualified staff. Last, employment measures need to be preceded by functional reviews to identify over or under-staffed sectors.

\section{Data}

Government wage bill and government employment data are drawn from the IMF FAD Government Compensation and Employment Dataset (IMF, 2016c). For most of the countries, wage bill corresponds to the general government, though for few countries the coverage is the non-financial public sector or central or budgetary government. There are also important comparability data issues-for example, regarding the recording of bonuses or in-kind benefits.

\footnotetext{
${ }^{10}$ One caveat when comparing employment across countries is that variations may reflect national choices about the role of governments and size of private sector service provision; measures to downsize the wage bill have to be evaluated in this context.
} 
The availability of government employment data is more limited, and these data refer to public or general government. A detailed description of key data challenges when comparing wage bill spending and employment across countries using this dataset can be found in Box 1 of IMF Policy Paper (2016f).

The wage premia refers to the public-private sector wage differential not explained by differences in the skill mix, and it is expressed in percent of private wage. These data are drawn from the IMF FAD Public-Private Wage Premium Dataset and focuses on the public sector rather than on the narrower general government wage (IMF, 2016d).

\section{Case study}

Over the last decade, government spending on the wage bill has been increasing and it is currently above the mean for the comparator groups. After a gradual decline in 2000-04, the wage bill has increased by nearly 6 percentage points since 2004, reaching about $12^{1} \frac{1}{2}$ percent of GDP in 2015 . The public wage premium chart indicates that the average compensation in the public sector is about 13 percent higher than in the private sector, close to the EMs premium average. However, public employment level is relatively high, exceeding the EMs average of around 8 percent of the labor force, and thus, seems to be the main driver behind the high wage bill spending.

\section{Investment}

Figure 5 displays public and private investment trends for the country of choice and several quantity and quality output indicators. The stock of capital informs about the appropriateness of past and current investment spending.

Qualitative indicators on infrastructure adequacy across all areas of transport infrastructureroads, ports, railroads and air transport infrastructure-are also provided. The relationship between the public capital stock and infrastructure quality indicators informs on investment efficiency. As found in previous research, many countries have considerable room to improve the efficiency of public investment (IMF, 2015c).

\section{Data}

The investment and public capital stock series are drawn from WDI, WEO, and IMF Investment and Capital Stock Dataset (IMF, 2016c). Public investment is measured using gross fixed capital formation of the general government. Private investment is also measured using gross fixed capital formation. Public capital stock refers to the general government capital stock and was constructed using the perpetual inventory method. ${ }^{11}$

\footnotetext{
${ }^{11}$ The document "Estimating Public, Private, and PPP Capital Stocks" (IMF, 2015a) describes in great detail the investment series' definitions as well as the methodology in constructing the stock series.
}

Technical Notes and Manuals 17/06 | 2017 
The quality of infrastructure ranking is based on an opinion survey from the World Economic Forum's Global Competitiveness Report (WEF, 2015). The ranking of 1 refers to the best performer among 144 reporting countries.

\section{Case study}

Argentina's relatively low public capital spending levels, and albeit a steady pick up, has translated into a low level of capital stock and poor infrastructure quality outcomes-in particular in air and road transportation-when compared to peer countries. ${ }^{12}$ Public capital spending as a share of GDP has been on an increasing path since 2002, while private investment has been declining since 2007, and currently stands at about 31/2 percent of GDP.

\section{Energy Subsidies}

Assessing energy subsidies holds the potential both to generate fiscal savings and to improve equity in all country groups. Studies have shown that energy subsidies can cause environmental damage, impose large fiscal costs, discourage investment in renewable energy, and enlarge the income inequality gap as the largest share of the subsidy benefit is usually captured by upper-income groups (Clements et al., 2013; Coady et al., 2010; Coady et al., 2015; and IMF, 2013a). Eliminating these generalized transfers while implementing measures to mitigate the adverse impact on the welfare of low-income households-such as targeted income or inkind transfers-can be both cost-effective and equity-enhancing. Understanding the current magnitude and nature of energy subsidies is the first step towards reforming them.

Figure 6 displays country-level data on estimated total energy subsidies for the country of choice and regional comparators. Information on total energy subsidies by energy productincluding petroleum, coal, natural gas and electricity-is presented. The breakdown of the total or post-tax energy subsidy by component-pre-tax, foregone consumption tax, and externality-is also displayed, to provide a comprehensive picture of the impact of the subsidy on expenditures, revenues, and the environment. ${ }^{13}$

\section{Data}

Energy subsidy estimates are drawn from the IMF Energy Subsidy Estimates Dataset (IMF, 2016b) published alongside the paper "How Large Are Global Energy Subsidies?" (Coady et al., 2015), which describes in detail the methodology used for estimating the subsidies.

\footnotetext{
12 In addition to low capital spending levels, efficiency could also be responsible for the relatively low investment outcomes.

${ }^{13}$ Pre-tax subsidy refers to the difference between the cost of supplying energy and the price paid by consumers (that is, firms and households). Post-tax consumer subsidy refers to the pre-tax subsidy plus an appropriate "Pigouvian" (or "corrective") tax that reflects the environmental damage associated with energy consumption and an additional consumption tax raised when applying the prevailing rate of value-added tax (VAT) or general sales tax (GST) that applies to consumer goods in the country to the energy supply cost plus the externality cost (Coady et al., 2015).
} 


\section{Case study}

Post-tax energy subsidies in Argentina in 2014 amounted to around 5 percent of GDP. This was comparable to the EM median of 5.3 percent of GDP, but higher than the OECD median of 1.6 percent, and the LAC median of 4 percent. The breakdown by product shows that in Argentina natural gas and electricity account for most of the post-tax subsidy, estimated at 2 percent and 1.8 percent of GDP, respectively, and petroleum subsidies account for only 1.1 percent of GDP. This subsidy structure contrasts with both LAC and EM medians, that show larger shares of petroleum subsidies within the post-tax total. The OECD median country also has higher shares of petroleum and coal subsidies than Argentina.

The second chart provides information on the composition of the energy subsidies and reveals that the externalities derived from the energy subsidies in Argentina are relatively small compared with other LAC countries. Among the three subsidy components and for the totality of the energy products, pre-tax subsidies account for the biggest share (2.4 percent of GDP) of Argentina's post-tax subsidy buildup, followed by externalities (1.5 percent), and foregone consumption tax revenue (1.2 percent). Taking a closer look at petroleum, the subsidy structure differs, in the sense that the post-tax subsidy of 1.1 percent of GDP reflects only the externality and the foregone revenue components. In contrast, the LAC, EM and OECD median estimates for the externality component of the energy subsidy account for the largest shares, at 2.2, 3.9 and 1.3 percent of GDP, respectively.

In general, the level of post-tax subsidies in Argentina in 2014 were comparable to those in other LAC and EM countries. Yet, Argentina's above average pre-tax subsidy level (3 times the LAC median) leaves room for further work on subsidy elimination.

\section{GOVERNMENT SPENDING BY FUNCTIONAL CLASSIFICATION}

The functional classification of expenditures provides information on the purpose for which an expense was incurred. The assessment of expenditures by functional classification focuses on three functions: health, education and social protection. The tabs "Health", "Education" and "Social" display the charts for the corresponding benchmarking analysis.

\section{A. Health}

Health care spending, usually a big item in the government budget, is projected to put pressure on government budgets in many economies in the coming decades (IMF, 2014a). Public health expenditure averages about 63/4 percentage points of GDP in AEs, while in EMs and LIDCs, public health expenditure is much lower. Aging populations are putting pressure for further increasing health spending in AEs, and the challenge is to stabilize the ratio of public health spending to GDP without adversely affecting health outcomes. EMs and LIDCs have pressures to expand the 
health-care provision. Hence, it is crucial to monitor health care dynamics to accommodate these demands in a fiscally sustainable manner and without affecting health outcomes.

Figure 7 benchmarks health spending and different modalities of health service provision to those in comparator countries. Various health expenditure metrics-for example, overall health (in percent of GDP and in per capita terms) —and indicators of the role of the public sector in the provision of health services (such as the share of total health expenditure provided by the public sector) are presented. An indicator to compare out-of-pocket health expenditure against the comparator groups is also included to inform about access and coverage of health insurance. In addition, the trends of total health spending in relation to GDP and of the share provided by the public sector are shown for the country of choice to help assess past dynamics.

Delivering quality outcomes is key given the growing demand to raise health spending in all countries. Tackling health system inefficiencies holds great potential for creating fiscal space and accommodating demands for additional health spending related to aging populations. In the case of emerging and LIDCs, addressing inefficiencies could result in increasing life expectancy. Indeed, simply increasing public expenditure in the health sector may not significantly affect health outcomes if the efficiency of this spending is low. The literature finds that the potential gains from reducing health system inefficiencies are large (Celasun et al., 2015; Coady, Francese and Shang, 2014; and Grigoli and Kapsoli, 2013).

The health efficiency frontier allows to examine the scope for improvements in health spending effectiveness. The chart plots Healthy Life Expectancy (HALE) as output on the vertical axis and total health expenditure per capita on the horizontal axis. The distance to the efficiency frontier, which is a best practice frontier, provides information on the loss in HALE due to health system inefficiencies. ${ }^{14}$ The distance to the frontier also informs on potential savings without compromising health outcomes. The bigger the distance to the efficiency frontier, the more inefficient a country is in providing health services. ${ }^{15}$

Additional health outcome indicators are provided, including the number of infant deaths, life expectancy, and availability of physicians, nurses and hospital beds.

If health system inefficiencies are identified, a more granular analysis is required to conclude that there is space to enhance the efficiency of spending. Through comparing efficiency gaps in the country of choice with those observed in peer economies, the analysis presented allows to control to some extent for some economic or social determinants of health. Still, it would be more accurate to control for factors beyond the control of the health system and affecting health

\footnotetext{
${ }^{14}$ HALE adjusts standard life-expectancy measures for severity of illnesses and quality of life factors. Factors such as the quality of health care environment are not taken into account. HALE is calculated by subtracting the years of ill health (weighted according to severity) from overall life expectancy.

${ }^{15}$ As total health expenditure comprises both the public and private sector, the analysis of efficiency refers to the effectiveness of total health spending, and not just to the effectiveness of public health spending.
} 
outcomes. Examples of these factors are per capita income, educational attainment, and access to sanitation facilities and clean water (Celasun et al., 2015). ${ }^{16}$

\section{Data}

HALE data are drawn from the WHO, and the rest of the health data from the WB.

The efficiency frontier is calculated using Data Envelopment Analysis (DEA) technique, which provides efficiency scores based on the input and output variables. DEA involves an application of linear programming methods where the frontier is built by connecting the bundles of units (countries) for which no other unit (country) produces the same or more output with a certain amount of input. The DEA frontier is the line that connects those bundles and is convex (Charnes, Cooper and Rhodes, 1978; Grigoli and Kapsoli, 2013; Seiford and Thrall, 1990).

\section{Case study}

Health outcomes are good in Argentina. Health outputs, such as number of infants, HALE, life expectancy at birth, and number of physicians, are more favorable in Argentina than the LAC and EM average.

The good health outcomes reflect in part total health expenditures exceeding those in comparator countries. Since 2009, total health expenditure (as a percent of GDP) has declined, mainly reflecting a reduction in public health expenditure. Despite this recent decline, total health expenditure in Argentina is slightly above the average LAC and EMs, when expressed in per capita, PPP\$ adjusted terms.

Also, good outcomes in Argentina reflect a relatively good efficiency of total (public and private) health spending. The loss in HALE due to spending inefficiency is small and is below the EM average. The chart also reveals that the same HALE could be attained by spending less. A detailed analysis of the health system would be needed to provide options that could generate savings without adversely affecting health outcomes. A caveat is that the extrapolation of these findings to the public health sector depends on the assumption that private and public sector are equally efficient.

\section{B. Education}

Education spending is also typically a high share of total public spending. Challenges countries face differ across income groups. EMs and LIDCs need to expand education coverage to tackle low enrolment rates while responding to demands for additional education spending associated

\footnotetext{
${ }^{16}$ Celasun et al. (2015) also notes that it is important to include other factors such as natural endowments (i.e. data on temperature, precipitation, percent of population affected by natural disasters, and geographical differences across countries), life expectancy in the early 1800 s to control for genetic and cultural differences, habits such as tobacco use and alcohol consumption, and other conditions beyond the control of the health system.
} 
with the projected increase in school-age population. In many AEs education spending has increased while the share of the school-age population has declined, and such increase in the cost of education per pupil has not necessarily been associated with better education outcomes. The challenge for many AEs is to adapt to aging populations and reorienting primary and secondary education spending toward age-related spending, like health or pensions, while addressing education spending inefficiencies (IMF, 2014a).

Figure 8 displays a range of education spending metrics against the comparator groups. Government education spending is presented in terms of GDP and government expenditure. Information on education spending per student by education level is also presented to help assess if there is an over or underspending of one level of education, such as tertiary education. Last, teacher-student ratios could help inform if an over or undersized education system is driven by either the wage bill and/or spending on goods and services.

Information on education spending is complemented with education outcomes to identify the potential for enhancing spending efficiency. The relationships between different combinations of education inputs and outputs by education level are analyzed. Teacher-student ratios and education spending per student (in PPP\$ terms) are used as inputs. Net school enrolment and secondary-education overall PISA scores are used as outputs. ${ }^{17,18}$

As in the case of health, if the frontier analysis reveals education system inefficiencies, a deeper analysis is warranted. First, a more thorough assessment of the inefficiency gap, for example, by controlling for other determinants affecting education outcomes-for example, geographical determinants and private education spending —is needed. This detailed assessment will also help in the identification of measures that a country needs to implement to enhance its efficiency of spending.

\section{Data}

Data on education expenditures, teacher-student ratios and education outcomes is drawn from the WB. As in the case of health expenditure, the efficiency frontier is calculated using DEA technique.

\section{Case study}

Public education spending in Argentina is high relative to other EM and LAC countries. Though Argentina's public spending on education in terms of percentage to GDP is slightly

\footnotetext{
${ }^{17}$ Net school enrolment in primary (secondary) schooling refers to the number of children enrolled in primary (secondary) school who belong to the age group that officially corresponds to primary (secondary) schooling, divided by the total population of the same age group.

18 The Program for International Student Assessment (PISA) is a worldwide study by OECD in member and nonmember nations that assesses the competencies of 15-year-olds in reading, mathematics and science. The last version available is for 2012. The 2015 version of the test is expected to be published by end-2016.
} 
above the average for peer economies, spending per student stands well above, in particular for secondary education. High student-teacher ratios-mainly for secondary but also for primary education—seem to be responsible for this gap.

Consistent with the elevated education spending, Argentina has a good education performance, but the frontier analysis reveals large spending inefficiencies in secondary education. For secondary education, student test scores and net enrolment rates are above the EM and LAC averages, but Argentina lies far from the efficient frontier. Tackling education inefficiencies in secondary education holds great potential for generating fiscal savings without jeopardizing educational outcomes. The design of such reform will need to be preceded by a more thorough analysis of the education system.

\section{Social Protection}

Social assistance programs comprise non-contributory transfers in cash or in-kind. ${ }^{19}$ As the goal of these programs is contributing to alleviating poverty and addressing income inequalities, in addition to the size of social assistance spending (expressed in percentage of GDP), the charts in Figure 9 show information on coverage and incidence to help assess how well these programs are targeted at the poor and vulnerable. ${ }^{20}$ Better targeted transfers enhance the poverty-reducing impact of social assistance. However, in practice and as noted in Clements et al. (2015b), IMF (2013b) and IMF (2014a), social assistance programs in developing economies suffer from low coverage of lower-income population segments and leakages of benefits to high income groups.

Several income distribution indicators are presented to provide insights about the need and adequacy of redistributive programs. These indicators include income share held by highest 10 percent, income share held by bottom 20 percent, and Gini coefficient. ${ }^{21}$

The bottom chart summarizes quantitative and regulatory indicators on public pension spending, which is one of the largest items in the budget and also an instrument for social policy. The retirement age by gender is one of the most important regulatory characteristics of any public pension scheme. Several quantitative indicators are also displayed, including public pension expenditures as a percent of GDP, and the old age dependency ratio (people aged 60 and older as a share of the 15-59 population), which reflects the current and expected demographics. Coverage is captured with the eligibility ratio defined as pensioners as a share of the elderly-this indicator could exceed 100 due to the presence of pensioners younger than

\footnotetext{
19 The ASPIRE project classifies social assistance into the following categories: unconditional cash transfers, cash transfers, social pension, food and in kind transfers, school feeding, public works, fee waivers and other social assistance.

${ }^{20}$ Coverage indicates the share of the poorest 20 percent of households that receive a social protection transfer. Benefit incidence indicates the share of total social protection transfers received by the poorest 20 percent of households.

${ }^{21}$ The Gini coefficient ranges between 0 in the case of perfect equality and 1 in the case of perfect inequality.
} 
population aged 65. Estimates on pension spending change over the next fifteen years give information on the expected pressures on pension spending that countries may face.

\section{Data}

Spending on social assistance and the coverage and incidence indicators are drawn from ASPIRE.

Pension indicators, including estimates on pension spending projections, are drawn from EPD pension database.

\section{Case study}

Income distribution in Argentina, when measured using the Gini coefficient and the income share of the top 10 percent, seems to be more favorable than in the rest of LAC, partly due to its higher social protection spending. Figure 9 shows that Argentina's social assistance spending and pension eligibility are higher than the average LAC.

Despite the more favorable income distribution, there is room to improve the social impact of the programs. At present, Argentina's share of income held by the bottom 20 percent is similar to the figures observed in the average LAC country. Indeed, though Argentina records a good benefit incidence for its social assistance programs, there is potential for enhancing the coverage of these programs, which is among the lowest in LAC.

\section{CONCLUSION}

This manual presents EAT, which is an easy and user-friendly tool for depicting and assessing government expenditures for any specific country. As illustrated with the case of Argentina, the tool provides information on expenditures-levels, composition and outcomes-and helps the user evaluate these through benchmarking against regional and income comparators.

EAT can be very useful for identifying areas to enhance efficiency or streamlining spending. However, as mentioned, EAT is not a substitute for a more in-depth analysis, but can provide useful initial analysis to identify areas where more refined assessment would be most warranted.

Future areas of work to enrich the analysis presented in the tool include the estimation of efficiency scores for health and education expenditures, and a detailed analysis of expenditures exploiting the cross-classification of expenditures by functional and economic classification once this data becomes widely available. 


\section{References}

Celasun, Oya, Francesco Grigoli, Keiko Honjo, Javier Kapsoli, Alexander D. Klemm, Bogdan Lissovolik, Jan Luksic, Marialuz Moreno-Badia, Joana Pereira, Marcos Poplawski-Ribeiro, Baoping Shang, and Yulia Ustyugova, 2015, "Fiscal Policy in Latin America: Lessons and Legacies of the Global Financial Crisis," IMF Staff Discussion Note 15/06 (Washington: International Monetary Fund).

Chailloux, Alexandre B., Nir Klein, and Christopher Wilson, 2016, "Public Expenditure Efficiency in Ireland," IMF Selected Issues Paper 16/257 (Washington: International Monetary Fund).

Charnes, Abraham, William W. Cooper, and Eduardo Rhodes, 1978, "Measuring the Efficiency of Decision Making Units," European Journal of Operational Research, Vol. 2, Issue 6, pp. 429-444.

Clements, Benedict, David Coady, Stefania Fabrizio, Sanjeev Gupta, Trevor Alleyne, and Carlo Sdralevich, 2013, "Energy Subsidy Reform: Lessons and Implications," (Washington: International Monetary Fund).

Clements, Benedict, Kamil Dybczak, Vitor Gaspar, Sanjeev Gupta, and Mauricio Soto, "The Fiscal Consequences of Shrinking Populations," 2015a, IMF Staff Discussion Note No. 15/21 (Washington: International Monetary Fund).

Clements, Benedict, Ruud de Mooij, Sanjeev Gupta, and Michael Keen, 2015b, "Inequality and Fiscal Policy," (Washington: International Monetary Fund).

Coady, David, Maura Francese, and Baoping Shang, 2014, "The Efficiency Imperative," Finance \& Development. International Monetary Fund, Vol. 51, Issue 4, pp. 30-32.

Coady, David, Robert Gillingham, and Rolando Ossowski, John Piotrowski, Shamsuddin Tareq, and Justin Tyson, "Petroleum Product Subsidies: Costly, Inequitable, and Rising," 2010, IMF Staff Position Note No: 10/05 (Washington: International Monetary Fund).

Coady, David, and Nan Geng, 2015, "From Expenditure Consolidation to Expenditure Efficiency: Addressing Public Expenditure Pressures in Lithuania," IMF Working Paper No. 15/278, (Washington: International Monetary Fund).

Coady, David, Ian Parry, Louis Sears, and Baoping Shang, 2015, "How Large Are Global Energy Subsidies?" IMF Working Paper 15/105, (Washington: International Monetary Fund).

Eurogroup, 2016, "Thematic Discussions on Growth and Jobs: Common Principles for Improving Expenditure Allocation," Eurogroup Statement and Remarks Press Release (Brussels), http://www.consilium.europa.eu/press-releases-pdf/2016/9/47244647137_en.pdf.

Gaertner, Matthew, and Maximilien Queyranne, 2015, "Status of Fiscal Adjustment and Challenges Ahead”, Portugal IMF Selected Issues Paper No. 15/127 (Washington: International Monetary Fund).

Grigoli, Francesco, and Javier Kapsoli, 2013, "Waste Not, Want Not: The Efficiency of Health Expenditure in Emerging and Developing Economies," IMF Working Paper No. 13/187 (Washington: International Monetary Fund).

Hallaert, Jean-Jacques, 2016, "Belgium: Making Public Expenditure More Efficient," IMF Selected Issues Paper No. 16/78 (Washington: International Monetary Fund).

Hallaert, Jean-Jacques, and Maximilien Queyranne, 2016, "From Containment to Rationalization: Increasing Public Expenditure Efficiency in France," IMF Working Paper No. 16/7 (Washington: International Monetary Fund). 
International Monetary Fund (IMF), 2013a, "Case Studies on Energy Subsidy Reform: Lessons and Implications," IMF Policy Paper (Washington), http://www.imf.org/external/np/pp/eng/2013/012813a.pdf.

_ _ 2013b, "Fiscal Policy and Income Inequality," IMF Policy Paper (Washington), http://www.imf.org/external/np/pp/eng/2014/012314.pdf.

_ - 2013c, "Rethinking the State-Selected Expenditure Reform Options," Country Report No. 13/6 (Washington).

_ , 2014a, Fiscal Monitor_Public Expenditure Reform: Making Difficult Choices (Washington), http://www.imf.org/external/pubs/ft/fm/2014/01/pdf/fm1401.pdf.

__ 2014b, Government Finance Statistical Manual 2014 (Washington), http://www.imf.org/ external/Pubs/FT/GFS/Manual/2014/gfsfinal.pdf.

__ 2015a, "Making Public Investment More Efficient: Annex I," IMF Policy Paper, (Washington), http://www.imf.org/external/np/fad/publicinvestment/data/info.pdf.

_ Stocktaking." IMF Policy Paper (Washington), https://www.imf.org/external/np/pp/ eng/2015/050715.pdf.

_ , 2015c, "Making Public Investment More Efficient," IMF Policy Paper (Washington), http://www.imf.org/external/np/pp/eng/2015/061115.pdf.

_ _ 2016a, "Case Studies on Managing Government Compensation and EmploymentInstitutions, Policies, and Reform Challenges," IMF Policy Paper (Washington), http://www.imf.org/external/np/pp/eng/2016/040816ab.pdf.

_ _ 2016b, "Country-level Energy Subsidy Estimates Dataset," (Washington), http://www.imf.org/external/np/fad/subsidies/data/codata.xlsx.

__, 2016c, "IMF FAD Government Compensation and Employment Dataset," (Washington).

__, 2016d, "IMF FAD Public-Private Wage Premium Dataset," (Washington).

__ 2016c, "IMF Investment and Capital Stock Dataset," (Washington), http://www.imf.org/external/np/fad/publicinvestment/data/data.xlsx.

__ 2016f, "Managing Compensation and Employment—Institutions, Policies and Reform Challenges," IMF Policy Paper (Washington), http://www.imf.org/external/np/pp/eng/2016/040816a.pdf.

Seiford, Lawrence M., and Robert M. Thrall, 1990, "Recent Development in DEA: The Mathematical Programming Approach to Frontier Analysis," Journal of Econometrics, Vol. 46, Issue 1-2, pp. 7-38.

World Economic Forum (WEF), 2015, The Global Competitiveness Index Historic Dataset, in "Global Competitiveness Report" 2005-2015, (Geneva). 
Figure 3. Government Spending and Economic Classification 1/

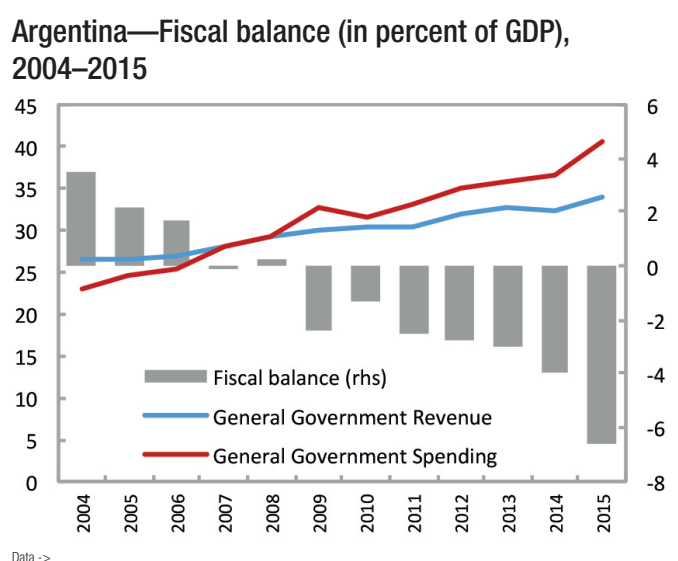

Change in Total Spending (in percent of GDP), 2004-2015

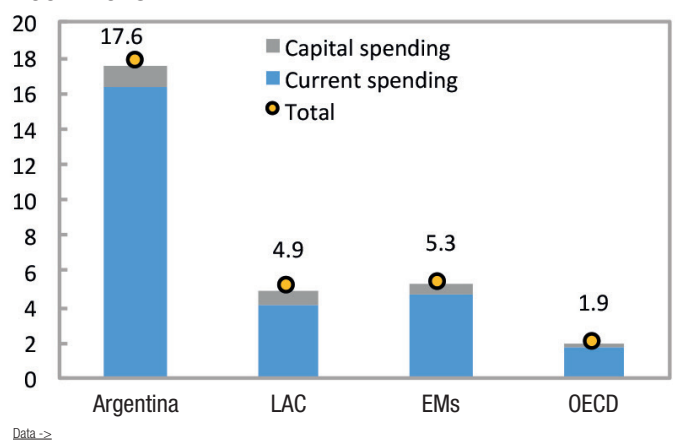

Argentina-Economic Classification (in percent of total), Latest Value Available

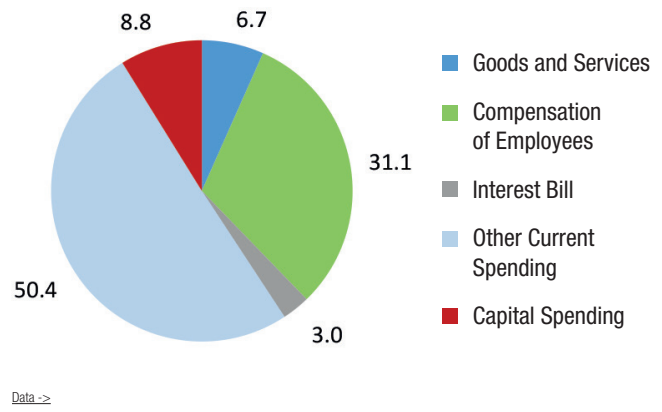

\section{General Government Spending}

(in percent of GDP) 2/

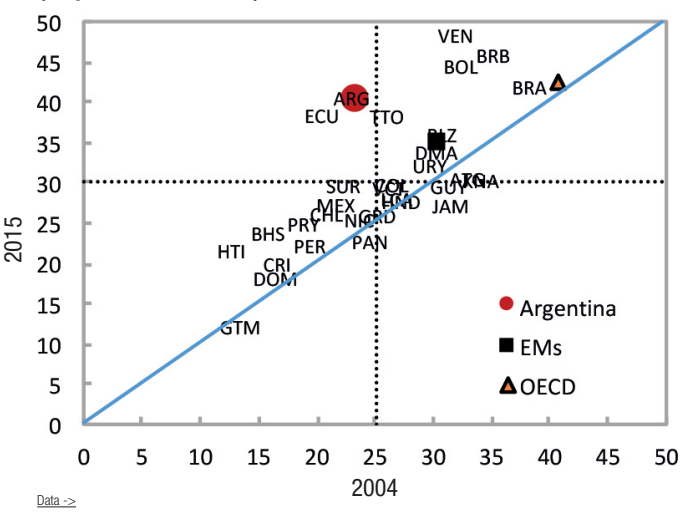

Current and Capital Spending (in percent of GDP), $20152 /$

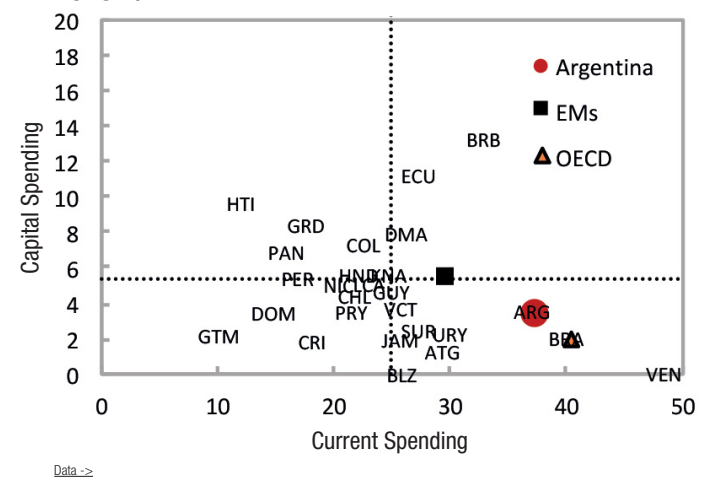

LAC-Economic Classification (in percent of total), Latest Value Available

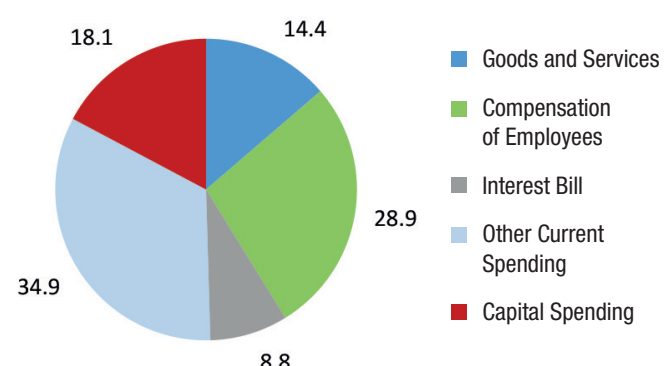

Data $->$

Source: IMF FAD Expenditure Assessment Tool (EAT).

1/ Coverage refers to general government as per World Economic Outlook.

2/ Dashlines are the average of LAC. 
Figure 4. Government Wage Bill
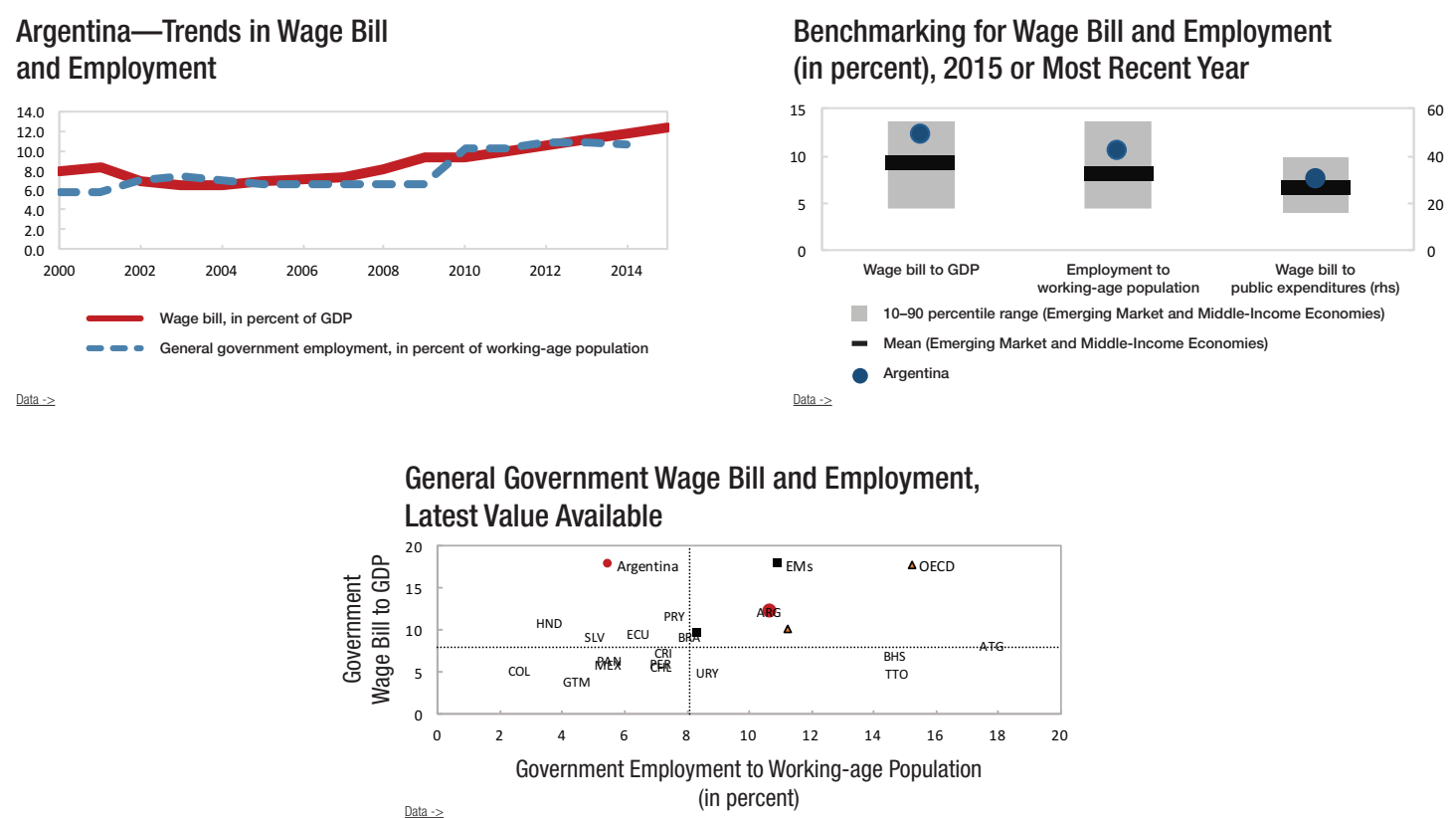

Wage Bill $1 /$

Latest Value Available (in percent of GDP)

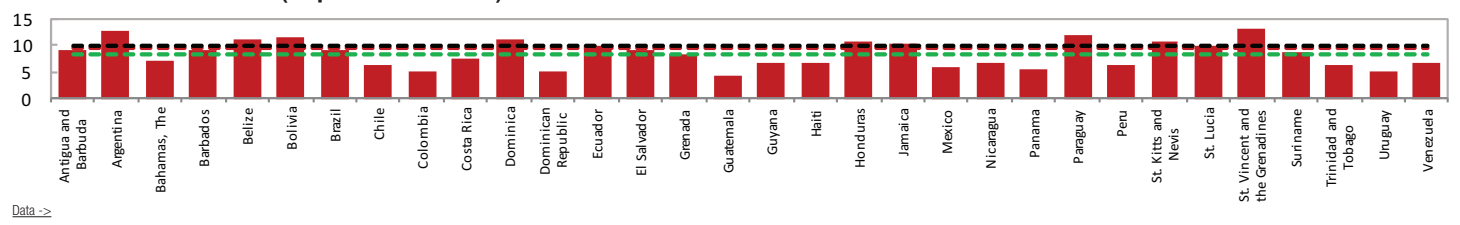

Wage Bill 1/

Latest Value Available (in percent of total spending)

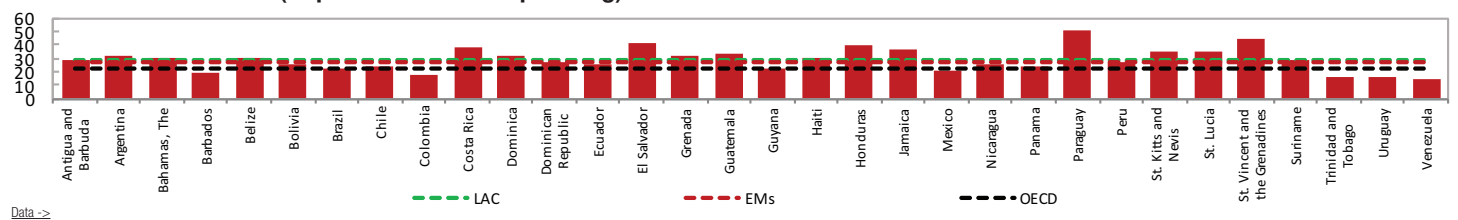

Wage Premia 2/

(in percent of private wage)

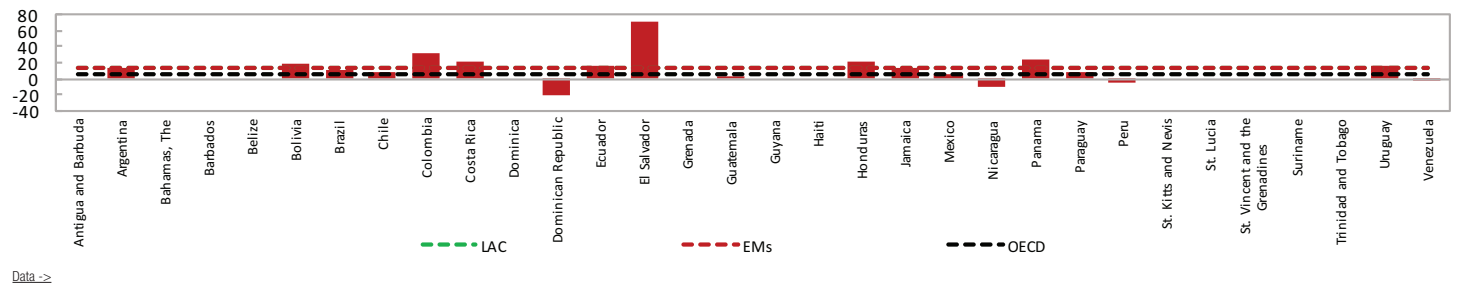

Source: IMF FAD Expenditure Assessment Tool (EAT). IMF FAD Government Wage Bill and Employment Dataset.

1/ Dashlines are the average for countries in the regional benchmark group.

2/ Public-private wage differential (as a percent of private wage); based on review of regression-based studies that control for skill differentials. 
Figure 5. Investment Infrastructure
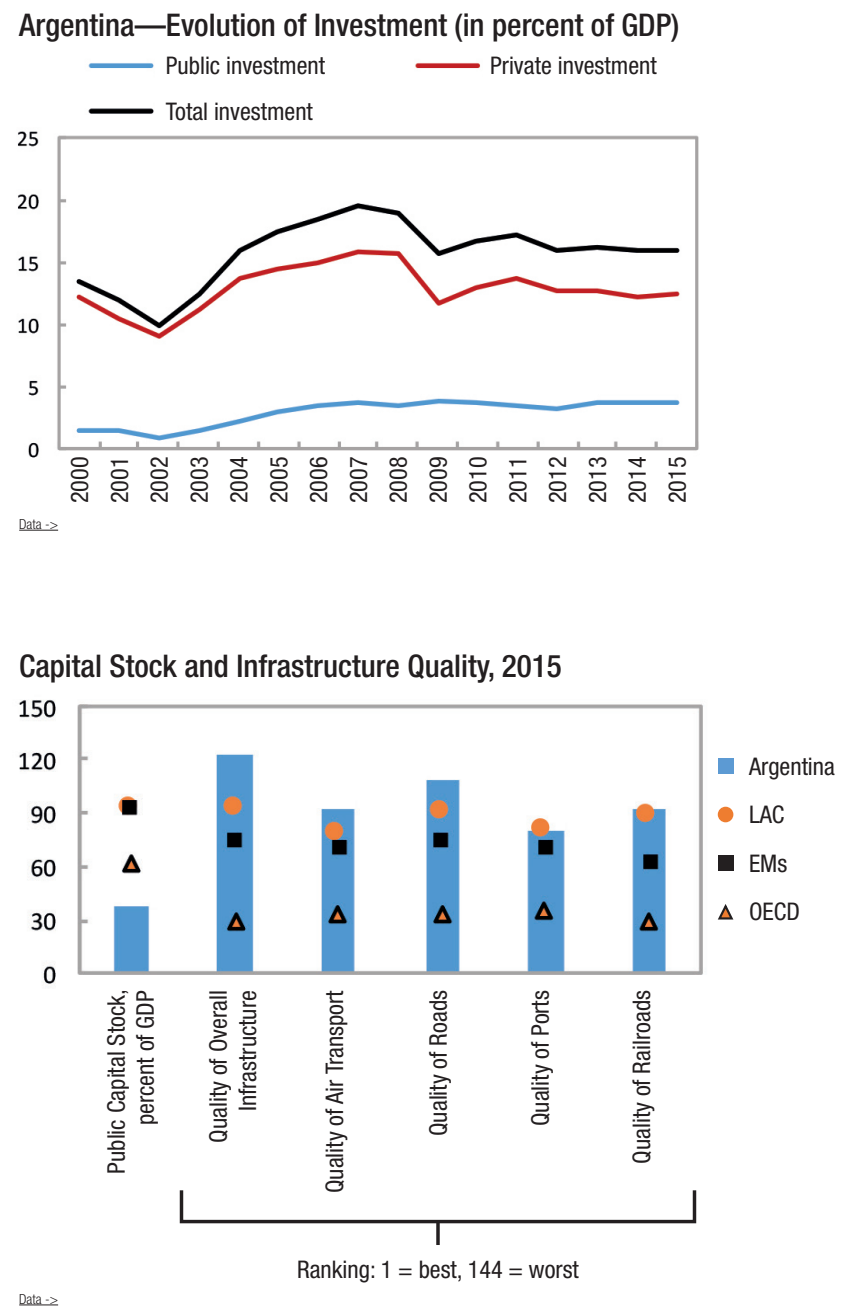

Source: IMF FAD Expenditure Assessment Tool (EAT), World Economic Outlook, World

Development Indicators, IMF Investment and Capital Stock Dataset, and World Economic Forum. 
Figure 6. Energy Subsidies

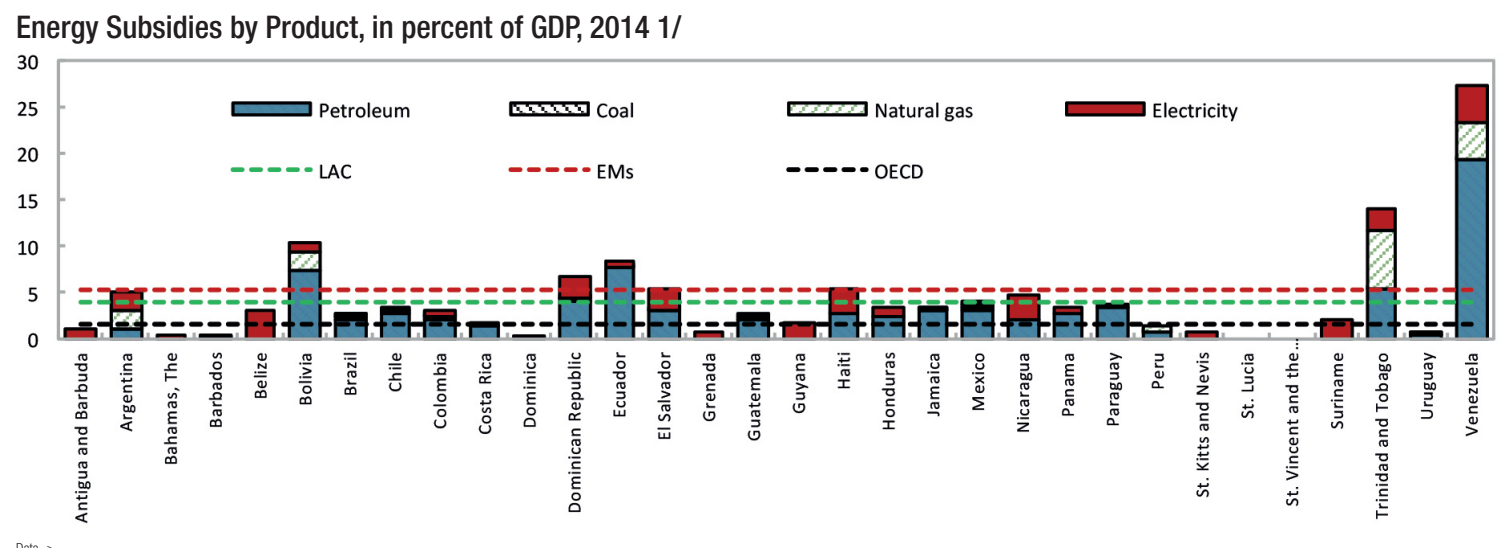

Energy Subsidies by Component, in percent of GDP, 2014 1/

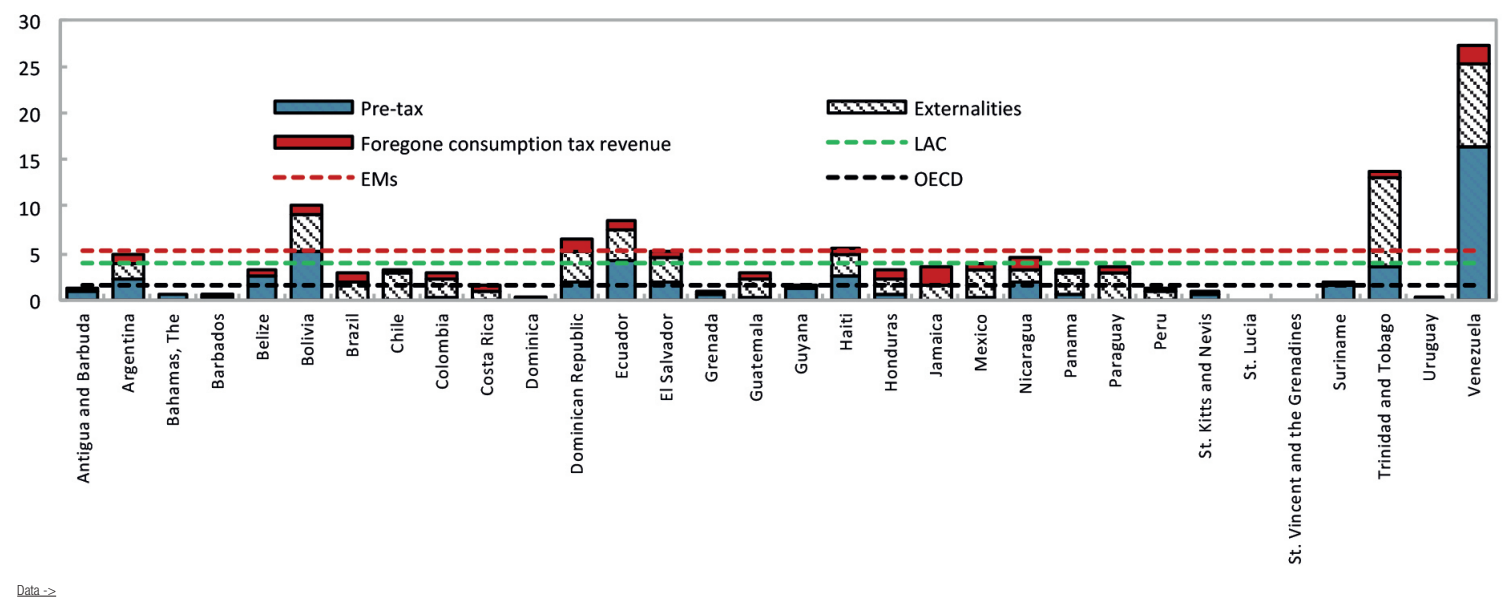

Source: IMF FAD Expenditure Assessment Tool (EAT), IMF Energy Subsidy Estimates.

1/ Dashlines are the median for countries in the region. 
Figure 7. Health Expenditure

Health Efficiency Frontier, Latest Value Available 1/
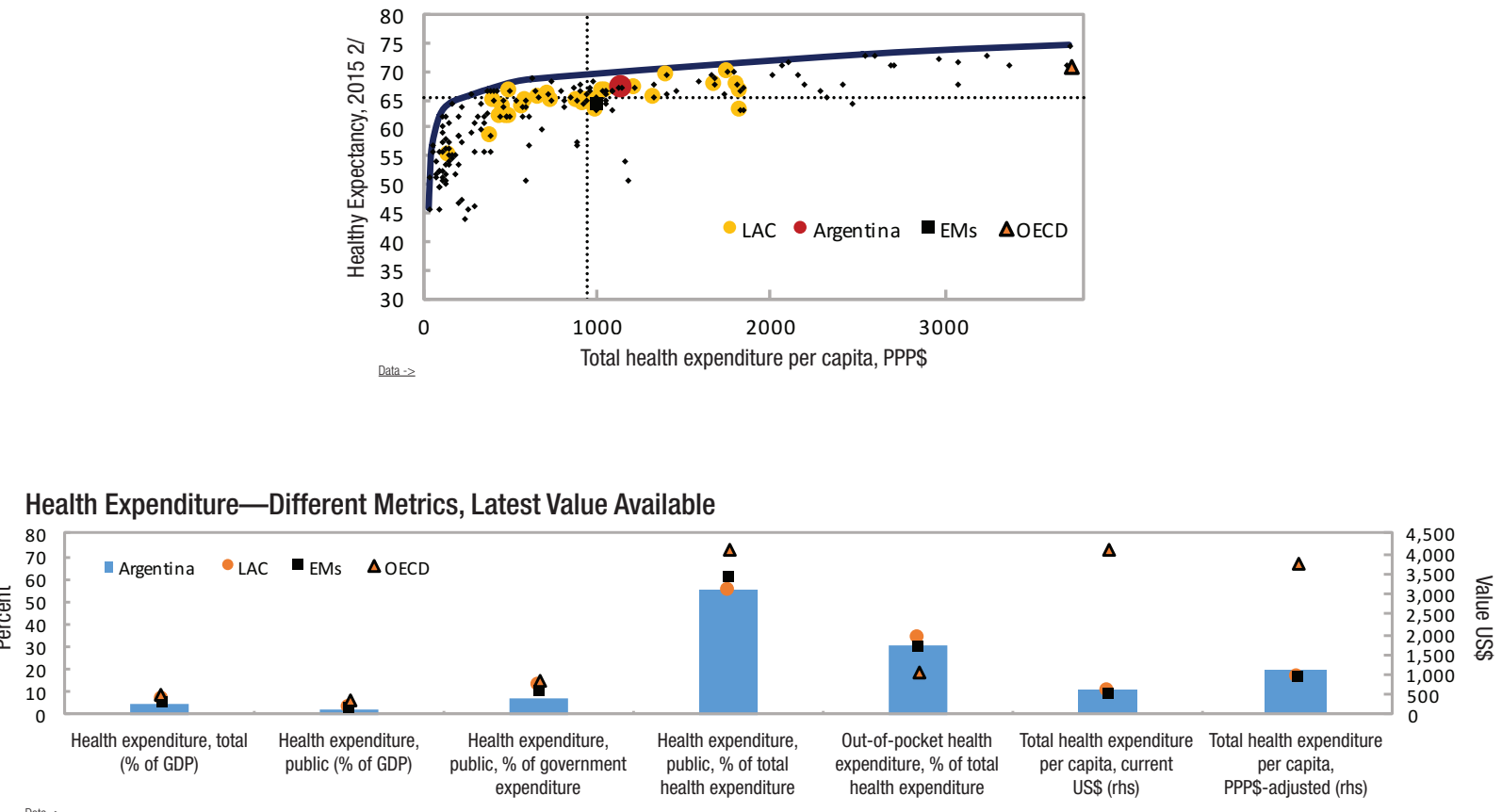
Data $->$
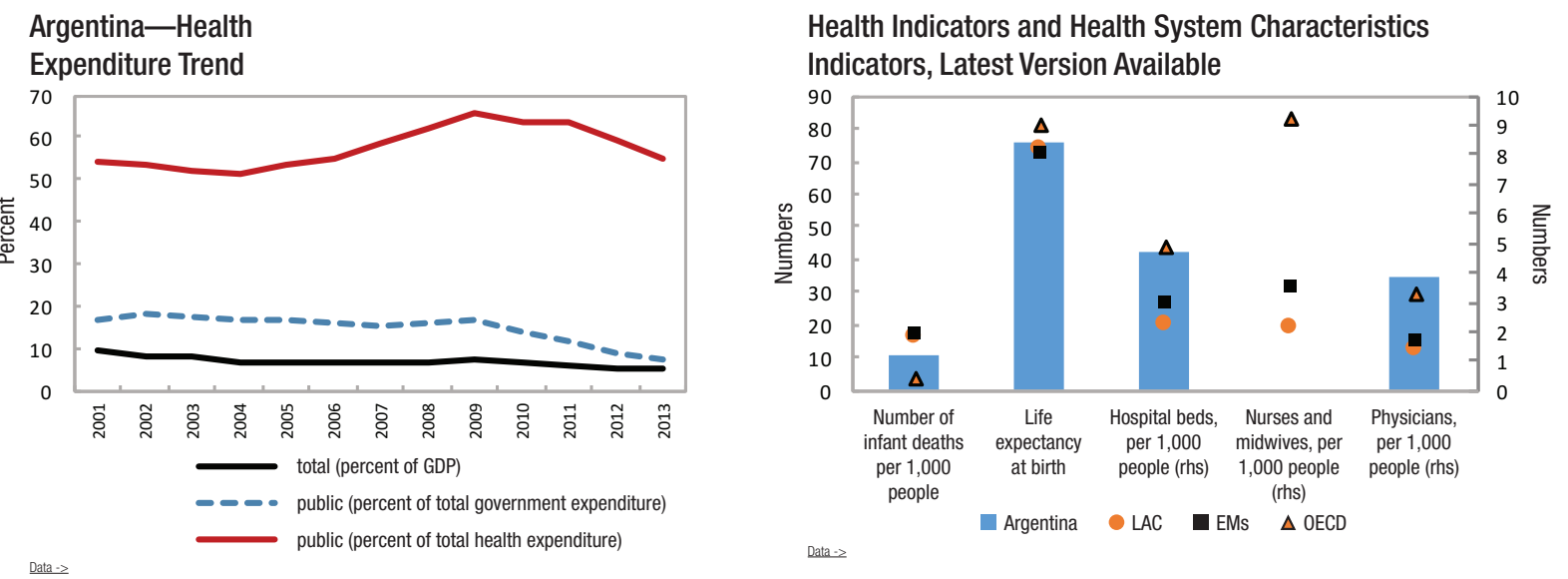

Source: IMF FAD Expenditure Assessment Tool (EAT), World Bank, World Health Organization. 1/ Dashlines are the average of LAC.

2/ Healthy life expectancy (HALE) is a measure of health expectancy that applies disability weights to health states to compute the equivalent number of years of life expected to be lived in full health. 
Figure 8. Government Education Expenditure

Government Education Expenditure, Latest Value Available

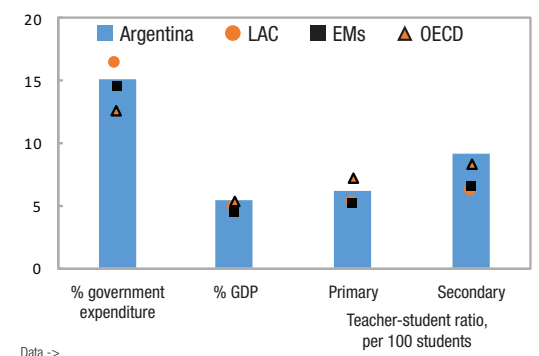

Teachers and Outcome, Primary, Latest Value Available 1/

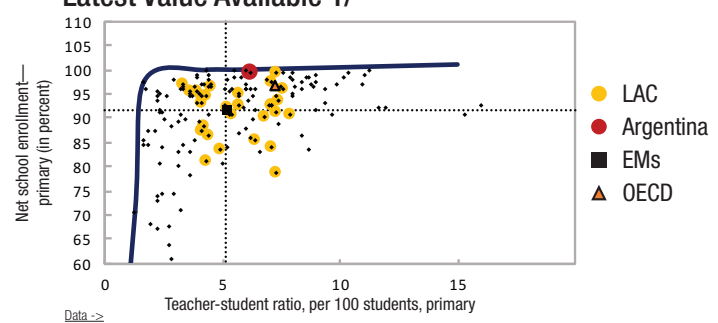

Government Education Spending and Outcome, primary, Latest Value Available 1/

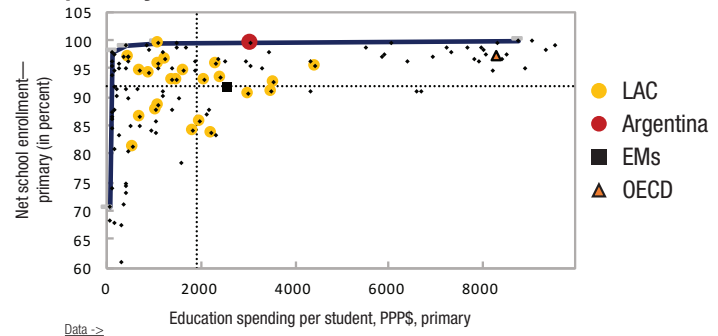

Teachers and Outcome, Secondary, Latest Value Available 1/

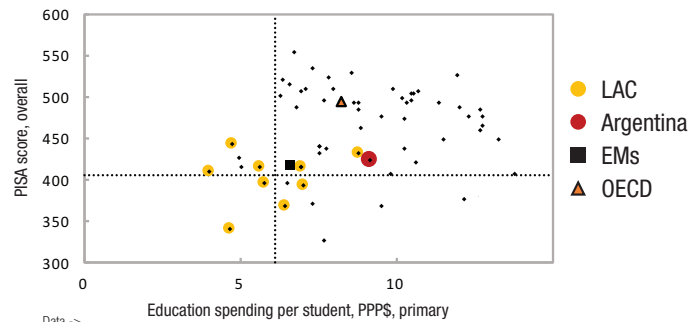

Government Education Expenditure per Student, PPP\$ adjusted, Latest Value Available

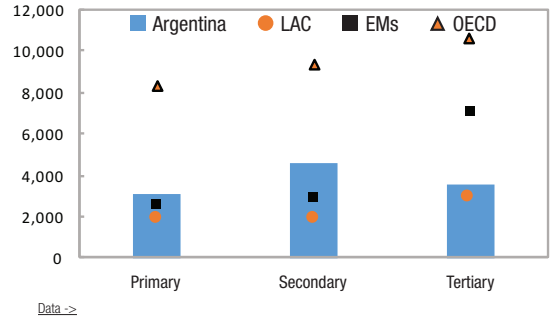

Teachers and Outcome, Secondary, Latest Value Available 1/

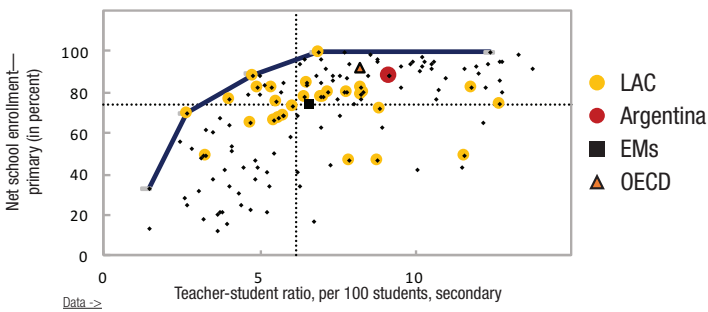

Government Education Spending and Outcome, Secondary, Latest Value Available 1/

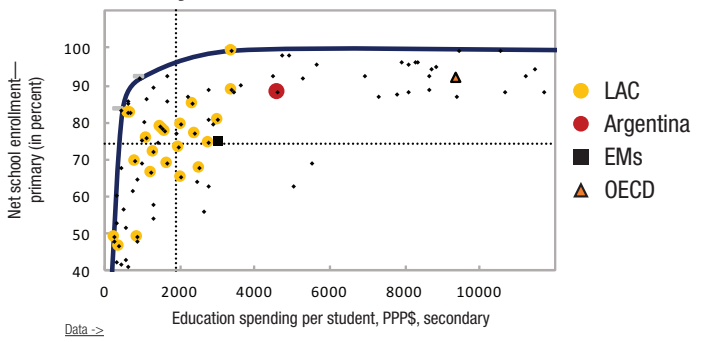

Government Education Spending and Outcome, Secondary, Latest Value Available 1/

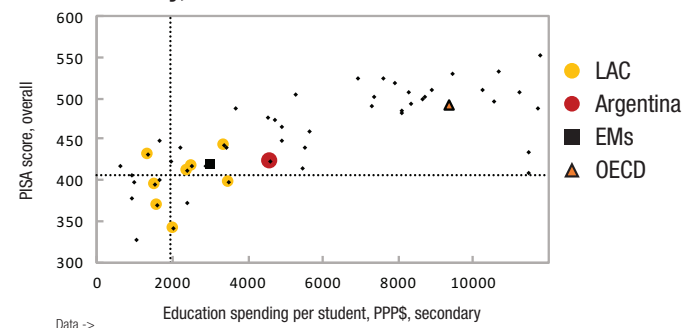

Education Indicators, Latest Value Available

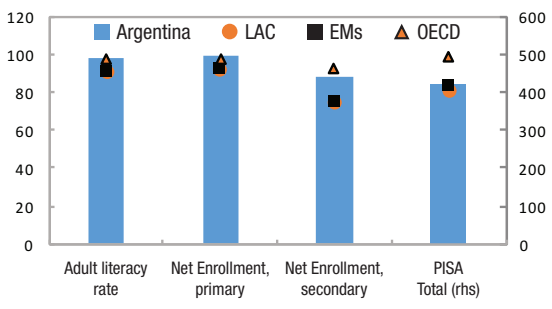

Data1.

Source: IMF FAD Expenditure Assessment Tool (EAT), World Bank.

$1 /$ Dashlines are the average of LAC. 


\section{Figure 9. Social Protection}

Social Assistance Spending (in percent of GDP), Latest Value Available

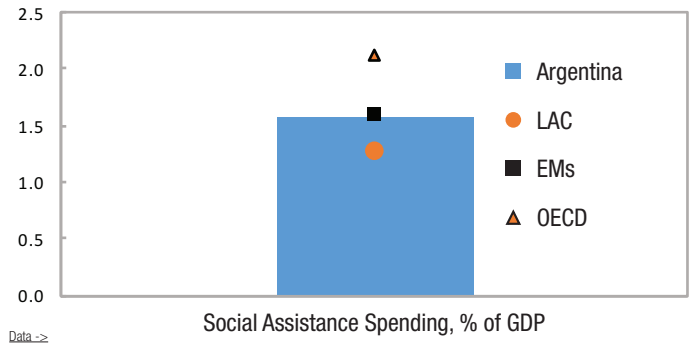

Population Indicators, Latest Value Available

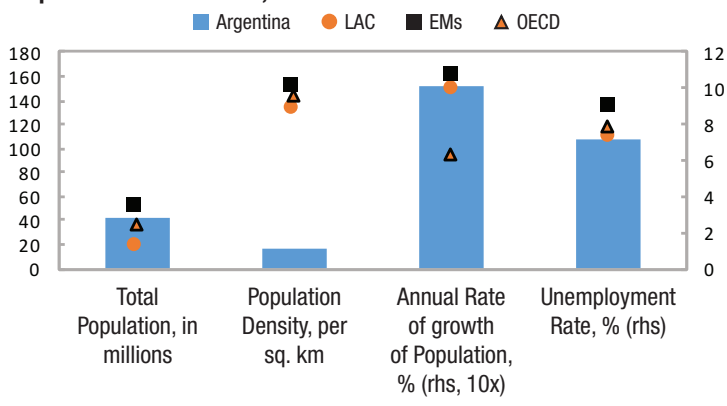

Social Assistance Coverage and Benefit Share of Poorest 20 percent (in percent),Latest Value Available 1/2/

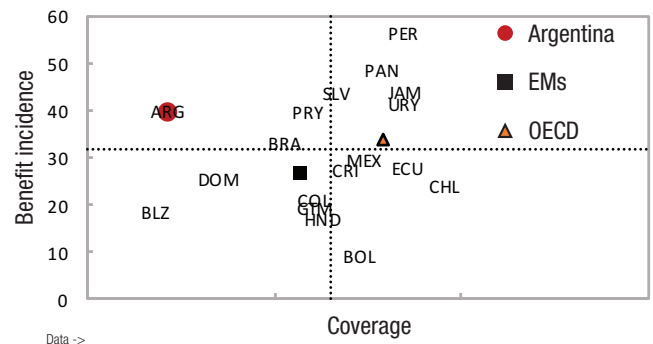

Income Distribution Indicators, Latest Value Available - Argentina $\quad$ LAC $\square$ EMs $\triangle$ OECD

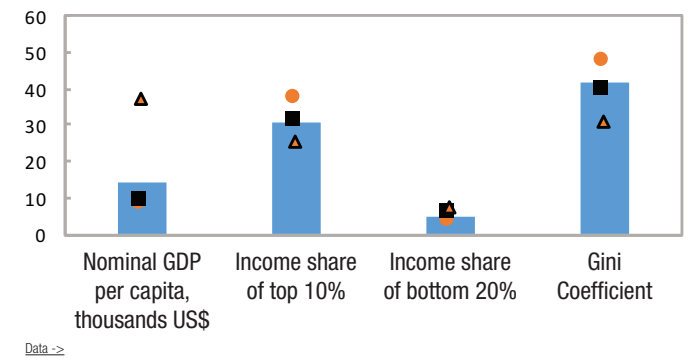

$\underline{\text { Data }-3}$

Pension Indicators, 2014

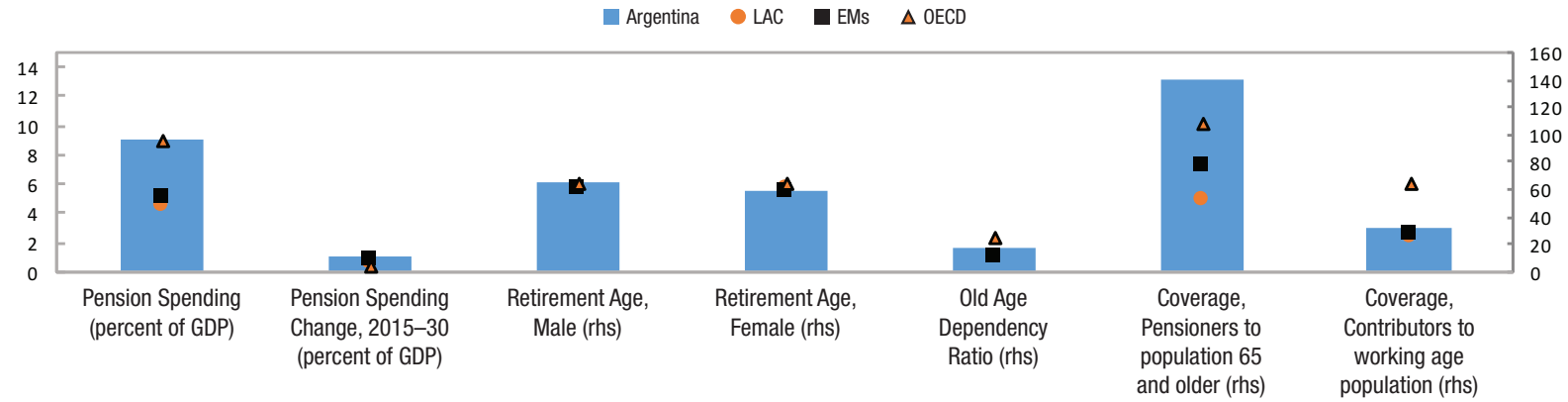

Source: IMF FAD Expenditure Assessment Tool (EAT), World Economic Outlook, ASPIRE and IMF Pension Indicators.

$1 /$ Dashlines are the average of LAC.

2/ Coverage is (number of individuals in the quintile who live in a household where at least one member receives the transfer)/(number of individuals in that quintile). Benefit incidence is equal to (sum of all transfers received by all individuals in the quintile)/(sum of all transfers). 


\section{TNM/17/06}

\section{International Monetary Fund}

Fiscal Affairs Department

700 19th Street NW

Washington, DC 20431

USA

Tel: 1-202-623-8554

Fax: 1-202-623-6073

ISBN-13: 978-1475592450

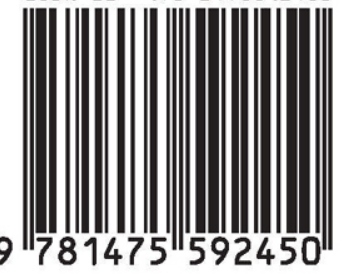

